\begin{tabular}{lcl}
\hline Bentham OPEN & Open Medicine Journal \\
CrossMark & Content list available at: www.benthamopen.com/MEDJ/ & $\begin{array}{l}\text { Open } \\
\text { Medicine } \\
\text { lournal }\end{array}$ \\
\hline
\end{tabular}

\title{
Early Stage Cervical Cancer, Therapy for Reproductive Health and Quality Survival
}

\author{
S. Chhabra* \\ Obstetrics \& Gynaecology Mahatma Gandhi Institute of Medical Sciences, Akansha Shishugruha Kasturaba Health \\ Society, Sevagram, Wardha, Mahatma Gandhi Adiwasi Dawakhana and Mata va Shishu Rugnalaya, Utavali, Melghat, \\ Amravati, Maharashtra, India
}

\begin{abstract}
Cervical cancer, one of the leading causes of cancer deaths, seventh in frequency amongst all the cancers, third most common cancer in women, after breast and colorectal cancers, accounts for $9 \%$ of all cancers in women and $4 \%$ of cancers in men and women put together. As cervical cancer is being reported in young women, so preservation of reproductive health and survival with quality has become more important during cervical cancer therapy. For quality survival, reproductive health preservation inspite of cancer, early diagnosis and appropriate therapy are essential. Purpose of this article is to share so that others also look into various issues and we try to do the best for prevention of cervical cancer and provide best therapy so that women have survival with quality and reproductive health is preserved, specially in young women. Review of literature was done and self experiences have been added.
\end{abstract}

Keywords: Cervical cancer, early stage, quantity life, reproductive health, therapy.

\section{BACKGROUND}

Cervical cancer is the seventh in frequency amongst all the cancers, third most common cancer after the breast and colorectal cancers, one of the leading causes of cancer deaths among women, specially in developing countries, including India. It accounts for $9 \%$ of all cancers in women, $4 \%$ of cancers in men and women put together. It is estimated that 530,000 new cases of cervical cancer must have been diagnosed in 2008 [1 - 3]. Worldwide, cervical cancer causes around 275,000 deaths per year, $80 \%$ in the countries with limited resources [4]. Though it is a preventable cancer, but continues to be a major cause of cancer related deaths globally. However if it is detected in early stage, death can be prevented, quality life is possible and even reproductive health can be preserved by appropriate therapy. Population-based studies from developed countries have shown marked socioeconomic gradients in the incidence and mortality due to cervical cancer. Women from lower socioeconomic strata have 2-3 fold higher risk to have cervical cancer than their affluent counterparts [5 - 10]. The difference is mainly because of the availability and utility of screening programs but it could also be related to other causes including diet. Most of the cases of the cervical cancer are because of infection with the human papilloma virus (HPV) and experts believe that a diet high in antioxidants, carotenoids, flavonoids, and folate found in fruits and vegetables can help the body fight HPV and also prevent conversion of cervical cells into cancerous cells by HPV. A study revealed that women who had high levels of certain chemical compounds indicating diet rich in fruits and vegetables were able to clear their HPV faster than their peers, reducing the risk of cancer [11]. It is number one cancer in women of East African and South Asian countries in terms of incidence as well as mortality [12]. More than eight out of ten (86\%) cases and $88 \%$ deaths due to cervical cancer occur in developing countries [3]. It is our experience that in a nearby province where diet is different, disease seems to occur more often in young women and seems to grow faster as young women report with advanced cancer compared to women of the province from where article is being written. Around $20 \%$ global cervical cancer cases are

\footnotetext{
* Address correspondence to this author at the Department of Obstetrics \& Gynaecology Mahatma Gandhi Institute of Medical Sciences, Akansha Shishugruha Kasturaba Health Society, Sevagram, Wardha, Mahatma Gandhi Adiwasi Dawakhana and Mata va Shishu Rugnalaya, Utavali, Melghat, Amravati, Maharashtra, India; Tel: +91-7152-284342-55, Ext: (O): 321, 307, (R): 221; Fax: +91-7152-284286; E-mail: chhabra_s@rediffmail.com
} 
from India [13]. However inspite of cancer, early diagnosis and appropriate management help in quality survival and preservation of reproduction health. Present article is based on review of the literature, experiences added for sharing and thought provoking.

\section{Diagnosis}

Many women who have cervical cancer report with vaginal discharge, with or without bleeding. This is sometimes preceded by postcoital bleeding. However there may not be noticeable symptoms or signs in early stages of cervical cancer. Unfortunately, cervical biopsy, the gold standard for diagnosis, is quite often not performed and the diagnosis is made after the woman undergoes simple hysterectomy for chronic vaginal discharge, creating many problems in further management. We get many such cases at this rural referral institute in eastern Maharashtra of India. It is essential that health professionals are made aware and they take appropriate action.

Improved imaging investigations such as high-resolution Computed Tomography (CT), Magnetic Resonance Imaging (MRI), and Positron Emission Tomography (PET), if done are likely to reveal extrauterine disease which is clinically not obvious. These investigative modalities are not used for staging in this part of the world because of the cost involved. Also these investigations do not detect micrometastasis which affect prognosis. Development of the nonotechnology based research in imaging technology is likely to help in the diagnosis of micrometastasis like the new Nanotechnology-Based Multiplexed Bioassay Platform for Diagnostic Applications project (NANO-MUBIOP) [14]. Nanotechnology might become one of the most promising technologies for the treatment of various cancers by creating drugs which will directly attack the cancer cells without damaging the other tissues. The treatment which has been tested in animal models, consists of a nanostructured composition encapsulating a protein called interleukin-2 (IL-2), lethal to cancer cells and a woman immunosuppressed by the disease produces less interleukin so the use of the nanoparticle is going to be very beneficial [15].

As of now, in this region the diagnosis is by cervical biopsy and staging is mostly clinical, sometimes by examination under anaesthesia. Cervical cancer is more often seen in low resource regions where it may not be possible to do CT or MRI and PET. So sometimes clinical, intra-operative and postoperative staging are not the same. We did a study and found clinical and intraoperative staging agreement in $72 \%$ cases and between clinical and final histopathologic staging 64\%, (unpublished). Knowing the extent and grade of cancer, helps in decision about the most appropriate therapy. However sometimes distant metastasis might be present in women with early invasive cancer or microinvasive cancer or even carcinoma in situ (stage 0), (disease only in innermost lining, no invasion), cases. Primary disease may be diagnosed while investigating/treating disorders because of metastasis. We had a case where the woman presented with fracture of the tibia. While managing the case it was revealed that she had secondaries of cervical cancer. Earlier the woman had gone to a health facility for vaginal discharge, the lesion on the cervix was diagnosed as cervical erosion clinically and chronic cervicitis on histopathology. So she was reexamined and submitted to repeat cervical biopsy. Re-evaluation turned out to be invasive cervical cancer (unpublished). So it was missed diagnosis. Another case diagnosed as cervical cancer in situ on cervical biopsy, when opened for laparotomy for simple hysterectomy (as she was many years beyond menopause and had follow up problems), revealed secondaries in the abdomen. Review of the slides of cervical biopsy was done which revealed micro invasive cancer, little beyond the first diagnosis of in situ cancer [16]. So sometimes local early disease could be advanced.

Cases with carcinoma in situ or stage 0, IA1 and IA2 with microscopic invasion not more than 3 mm deep, not more than $7 \mathrm{~mm}$ wide, more than $3 \mathrm{~mm}$ but not more than $5 \mathrm{~mm}$ deep, not more than $7 \mathrm{~mm}$ wide respectively, IB1 microscopic more than $5 \mathrm{~mm}$ deep or more than $7 \mathrm{~mm}$ wide or visible disease but $4 \mathrm{~cm}$ or less and in stage II A1 beyond the cervix but not to the pelvic wall or to the lower third, can only be called early stage cancers for all practical purposes [17]. In these cases single modality of therapy might be sufficient. Risk in cases of IB2, (larger than 4 centimeters tumour), IIA2 (more than $4 \mathrm{cms}$ with, vaginal involvement), IIB (spread to tissues around the uterus but not pelvic wall) are too advanced to be included in early stage though outcome in these cases is better than real advanced cases stage III and IV.

\section{THERAPY}

In addition to health education and screening (either mass or opportunistic) by various modes, Human Papillomavirus (HPV) vaccine is being recommended as a preventive strategy [18]. New research suggests that a single dose of vaccine is enough [19], however controversies about its use, because of various reasons continue. Cervical cancer occurs in poor women who cannot afford the vaccine and those who are being advised to get the vaccine rarely 
get cervical cancer and HPV free cancer is also known [20]. For quality disease free survival (DFS), treatment needs to be tailored to the extent of the disease. Since most cervical cancer cases have precancerous stage for years, prevention is possible and needs to be attempted by treating precancerous disease. Preservation of reproductive health is possible if the disease is diagnosed in early stage. It has become essential to work in this direction as younger women are getting the disease and women are postponing their child bearing. Appropriate selection of therapy is critical for the best outcome.

The modality of therapy depends on several factors, age, parity, tumour size, extent of disease, stage, grade, histology, evidence of lymph node involvement, risk factors for complications of surgery/radiation, associated medical disorders, desire of preservation of fertility and patient preference. Sixty-five years of age is cited as the limit for consideration of radical hysterectomy by some researchers [21], however morbidity and survival of older patients comparable to younger women have been reported [22]. It seems prudent to determine whether a surgical approach is appropriate and safe, based on stage, other risk factors independent of chronological age [23]. Three standard therapies are Surgery, Radiation or Chemotherapy used singly or in combination. Surgery, if possible is preferred, as the diseased part/organ is removed from the body, however it has to be safe and must lead to survival with quality. In selected cases of stage IA1, loop electrosurgical excision procedure (LEEP) performed in outpatient may be an acceptable alternative to cold-knife conization. It obviates the risks of general anesthesia needed for cold-knife conization [24, 25], however controversy exists as to the adequacy of LEEP, as a replacement to conization [26, 27]. Also unrecognized invasive disease treated with inadequate ablative therapy may be the most common cause of failure of therapy [28]. Further the use of LEEP in patients having occult invasive cancer might lead to inability of determining the depth of invasion accurately. A study has revealed that lymph-node involvement in these patients is low [29]. For women of postreproductive age who cannot or no longer wish to have children and follow up is a problem, total hysterectomy (vaginal/abdominal) is advocated. If surgery is not possible, internal radiation is advocated [30, 31]. It is the most common modality used in Indian women who complete their child bearing early. There is lack of awareness and also there are other problems like dependence, resources and follow up. Therapeutic strategies need deviations according to the situation. For rural poor women radical decisions are taken even for preinvasive disease. The classical surgical management of stage IA1 with lymphovascular space involvement, IA2, IB1, and IIA1 is radical hysterectomy (RH). Though conception in her own uterus is not possible as of today, ovarian preservation, sexuality, quality survival are possible with the possibility of having her own baby by surrogacy. Radical hysterectomy with node dissection is considered for patients where the depth of tumor invasion is uncertain because of invasive tumor at the margins of the cone taken out for diagnosis. In early stage, pelvic lymph node metastasis is expected in $10-15 \%$, in $17 \%$ cases of stage IB and $12-27 \%$ in stage IIA. In node negative patients, pelvic lymphadenectomy has low benefits, increases the risk of lymphocyst and lymphedema which affect quality of life [31, 32].

Intraoperative detection of metastasis by Sentinel Lymph Node (SLN) mapping with peritumor injection of radio isotope and blue dye with or without lymphoscintiography with a gamma probe has been proposed for identification of node involvement in early cancer. SLN can be subjected to extensive evaluation, immunohistochemistry to detect micrometastasis more accurately and minimize post-operative morbidity by avoiding unnecessary lymphadenectomy. However at present there is no clear evidence to support the use of sentinel node removal in preference to pelvic lymphadenectomy [33]. A combination of internal and external radiation which is usually advocated for IB2, IIA2 and IIB, may sometimes be best therapy, even for early stage cases (IA1, IA2 and IB1). Deep stromal invasion, large tumor size, and lymphovascular invasion are intermediate risk factors and if any of these are identified, adjuvant radiation decreases the risk of recurrence [34]. The selection of either option depends on various factors and expertise available. Radiation or radical hysterectomy with pelvic lymphadenectomy result in cure rates of $85-90 \%$. A randomized trial reported an identical 5-years survival and disease-free survival (DFS) after radical hysterectomy and radiation [35]. RH causes damage to the autonomic nerves . Damage depends on radicality of surgery. This might lead to bladder and sexual dysfunction as the nerves are also responsible for the increased vaginal blood flow during sexual arousal [36]. Based on various studies, nerve- sparing radical hysterectomy (NSRH) has been proposed as a means of preserving bladder, sexual function [37 - 42]. In NSRH identification of the bilateral inferior hypogastric and the splanchnic nerves is performed during pelvic lymphadenectomy. Identification of ureters below the level of common iliac vessels along the peritoneum of mesorectum is guided with careful dissection of peritoneum and the ureter followed by identification of the inferior hypogastric nerve 1-2 $\mathrm{cm}$ below the ureter. The nerve is dissected towards the uterine artery with simultaneous dissection of the inferior hypogastric nerve away from the uterosacral ligament at the lateral part of cardinal ligament [43]. 
Cunningham et al. [44] have reported that after surgical staging, patients with small volume, para-aortic nodal disease and controllable pelvic disease may be cured with pelvic and para-aortic radiation. Treatment by extended-field radiation in patients with unresected periaortic nodes leads to long-term disease control in low volume $(<2 \mathrm{~cm}) \mathrm{cases}$ [45]. Patients with close vaginal margins $(<0.5 \mathrm{~cm})$ may also benefit from pelvic radiation [46]. Hertel et al. [47] reported that cases of IB1 stage, with negative lymph nodes and absence of angiolymphovascular space involvement are the ideal candidates for laparoscopically assisted radical vaginal hysterectomy (LARVH). Proper case selection with restriction of the procedure to small tumors is essential even for the short-term surgical benefits of LARVH [48]. Less radical surgery in conjunction with pelvic lymphadenectomy (fertility preserving radical operation) is being advocated. In radical trachelectomy, cervix, upper vagina and surrounding tissue along with pelvic lymph nodes are removed. It is followed by Saline procedure to prevent preterm labour. Abdominal route results in wider parametrial resection than vaginal and also there are lower intra operative and post operative complications. In combined laparoscopic and transvaginal approach the reconstruction includes a strong nonabsorbable suture around the isthmus reattaching the uterine stump with vagina (prophylactic ciralage) and closure of the pouch of Douglas, taking care of not obstructing the uterine orifice. In a study with the mean follow up of 23 months, there were no recurrences [49]. Laparoscopic vaginal radical trachelectomy (LVRT) may be the most appropriate answer to the question of fertility preservation in the management of early stage cervical cancer for some women $[50,51]$ specially in the affluent world, for women of low resources the situation is very different because of problems of accurate staging and follow up. In invasive cancers simple hysterectomy has as high as $60 \%$ risk of recurrence [52]. When invasive cervical cancer is detected after simple hysterectomy, further treatment is either radiotherapy or radical parametrial resection, vaginal cuff removal and pelvic lymphadenectomy. Robotic radical parametrectomy with bilateral pelvic lymphadenectomy is also believed to be feasible and safe. It can be performed with an acceptable complication rate [49]. Geisler et al. [53] reported that robotic radical hysterectomy $(\mathrm{RRH})$ with pelvic lymphadenectomy is a promising new surgical technique. It has acceptable blood loss, operating time, clean parametrial margins, appropriate nodal yield and shorter hospital stay. Intra-operative and post-operative complications are comparable to open RH [54 - 56], but long-term outcome needs to be researched. Magrina et al. [57] reported operating times for RRH and RH through laparotomy similar, but significantly shorter compared to laparoscopic surgery. Blood loss and hospital stay are similar for laparoscopic and robotic surgery but significantly less compared to laparotomy. Sert [58] reported that Robotic-assisted laparoscopic radical hysterectomy in early stage cervical cancer has better results than total LRH but Kruijdenberg et al. [59] have reported that Robot assisted and total LRH are equally adequate and feasible. Research needs to continue.

\section{Radiotherapy/Chemotherapy}

Radiotherapy, (external and internal) is time tested therapy in all stages of cervical cancer, however in early stage radiation is reserved for women who are not surgical candidates. In early stage radiotherapy with or without chemotherapy is used only when surgery is not possible because of medical problems or because of patients choice or lack of expertise. Common side-effects of radiotherapy are of, fatigue, bowel, bladder dysfunction and skin problems which can be controlled with diet modification, exercises, oral rehydration and symptomatic therapy, even natural [60 62]. Recent reports revealed that radiation therapy for cervical cancer increases risk for colorectal cancers. Young women treated with radiation for cervical cancer should begin colorectal cancer screening earlier than traditionally recommended [63]. When chemotherapy is used, with radiotherapy for better efficacy of the radiotherapy to improve progression free survival, the drug is cisplatin, singly or in combination with 5 fluorouracil. It reduces local and distant recurrences also. The role of radiosensitizing chemotherapy in IA2 and IB1 lesions is untested and is likely to be of only marginal benefit since the cure rates with radiation alone exceed or approach 90\% [64]. Also research through nanotechnology is being done for targeted action [15, 65]. Jabir et al. [65] and Rotman et al. [66] report that the addition of concurrent cisplatin-based CT to RT significantly improves progression and overall survival for high-risk early stage patients who undergo radical hysterectomy and pelvic lymphanectomy. Toxic effects are greater with paraaortic radiation than with pelvic radiation alone but are mostly with prior abdominopelvic surgery. Although low-dose rate (LDR) brachytherapy with cesium Cs 137, has been the traditional approach. The use of high-dose rate, brachytherapy with iridium (Ir 192), is rapidly increasing, as it eliminates radiation exposure to medical personnel with a shorter treatment time and patient convenience.

Radiation in the range of 50 Gy administered for 5 weeks with cisplatin with or without fluorouracil (5-FU) should be considered in cases with high risk of recurrence including those with positive pelvic nodes, positive surgical margins, local micrometastasis [67]. 


\section{COMPLICATIONS}

Surgery is notoriously prone for postoperative complications such as urinary tract fistula, thromboembolism, lymphocyst, lymphoedema, and bladder dysfunction [39, 40]. Intraoperative and immediate post-operative complications of radical hysterectomy include blood loss, uretero-vaginal fistula (1- 2\%), vesico-vaginal fistula $(<1 \%$ o), pulmonary embolism (1- 2\%), small bowel obstruction (1- 2\%) and others like fever, deep vein thrombosis, pulmonary embolism, pelvic cellulitis, urinary tract infection (25-50\%). In the recent past, Trimbos et al. [43] have reported post operative mortality of $<1 \%$ but high morbidity, urinary tract infection $42 \%$, deep venous thrombosis $3 \%$ and fistula $2 \%$. Subacute complications include constipation, lymphocyst formation and lower extremities edema. Postoperative colonic stasis might persist for days [68]. Patients who undergo extraperitoneal lymph node removal have less bowel complications than those with transperitoneal route [45, 69 - 73]. Postoperative radiotherapy results in a significant deterioration of these functions. In high-risk, morbidly obese patients the safety of panniculectomy has been reported as a technical advantage and is achieved by improved operative exposure [74].

Disruption of autonomic fibres of the bladder during operation of the pelvic viscera is associated with significant bladder, anorectal, urinary and sexual dysfunction, but seems to be inevitable $[75,76]$. Functional disorders of the lower urinary tract are the most common long-term complications (8-80\%) due to partial interruption of the autonomic fibers innervating the bladder during resection of anterior, lateral and posterior parametrium and vaginal cuff leading to sensory loss, storage and voiding dysfunction and incontinence [77, 78]. Partial or complete denervation of the urinary tract results in collection in bladder and urethral dysfunction with negative impact on quality of life [79, 80]. However, research reveals that the size of lateral parametrium measured on giant sections does not differ among these cases. Reports reveal that the length of vagina removed is significantly longer in patients with detrusor dysfunction than in patients with normal diagnosis or genuine stress incontinence [81, 82]. Brooks et al. [83] reported that radical hysterectomy does not appear to be associated with more long-term bladder or anorectal dysfunction than simple hysterectomy. Severe anorectal dysfunction is uncommon. Zullo et al. [81] report that the pathophysiology of these changes is controversial. Ran et al. [82] reported that the retention of urine after radical hysterectomy is not related to loss of blood volume, parity and menopause.

\section{PROGNOSIS}

Many factors influence quality survival and reproductive health in early stage cancer, general condition, age, type, stage, response to treatment. Whether advances in diagnostic tools and therapeutic methods improve the overall prognosis of patients and recurrence is debatable but with appropriate treatment in early stages, cure rates go up to 90 $100 \%$ as reported by Lim et al. [84]. Prognosis is affected by undiagnosed parametrial disease, metastasis in pelvic lymph nodes, and positive surgical margins. Involvement of regional lymph nodes is one of the most reliable prognostic factor $[85,86]$. Actually node histopathology is considered to be the most important predictor after FIGO staging [87 89]. Rose et al. [73] reported that the risk of death from cervical cancer has decreased by $30-50 \%$ with use of concurrent chemoradiation.

Unfortunately some women with early disease do badly with conventional approaches [85] for reasons not very well understood. Over expression of genes seems to predict the prognosis, investigations which go beyond the reach of those who mostly suffer from this cancer. All said, most patients with early stage cervical cancer can be cured or their disease can be controlled for a period of time which varies from months to years with quality survival. If the disease recurs, the treatment depends upon the stage, past therapy and the condition of the patient. Optimal treatment for recurrent disease is still a debate. Most recurrences occur within 5 years [90], but recurrences beyond 5 years of radiation have been described [91]. Patients with early disease who undergo appropriate treatment have recurrence risk of 10-15\%, mostly isolated in pelvic cavity [92]. Fatemeh et al. [93] report mean interval of recurrence as $2.75+1.5$ years after the initial treatment. Earlier Comerci et al. [94] reported recurrence in $7.6 \%$ for stages I and II combined, Yamazawa et al. [95] report $25 \%$ recurrence in all stages combined, $35.7 \%$ in II. We still need to know the factors, which will allow the selection of patients with clinical early disease, who would benefit from more aggressive multimodality regimens from the outset. Factors which affect the final outcome and survival continue to be a dilemma. DFS correlates strongly with depth of tumor invasion, tumor size and capillary-lymphatic space invasion [96].

Dyun et al. [97] report average DFS of 18 months, close to findings of recent report of Ohara et al. [92]. Lim et al. [84] also reported an average DFS of 17.6 months but earlier Mahe et al. [98] reported an average DFS, 70 months. Hertel et al. [47] report that for recurrence-free survival, tumor stage, lymph node status, and combined involvement of lymphovascular and angiovascular space are independent prognostic factors. DFS may not be significantly different for 
age, disease status of the surgical margins, tumor description, quadrant involved with tumor, uterine extension, and keratinizing status of tumor cells. Clinical tumor size, and depth of tumor invasion are independent prognostic factors [99]. Final outcomes include, treatment related morbidity, pelvic floor function, patterns of recurrence, quality of life overall survival, costs and cost effectiveness [100, 101].

\section{CHALLENGES}

Unfortunately very few women report at operable stage in part of the world where cervical cancer is common [16, 102,103 ] and compliance during therapy and after therapy is low [16]. Further aggressive disease is being detected in younger women (25- 40 years) and old peak of occurrence of disease at 50-55 years has been replaced by plateu between 35-55 years [104, 105]. Recent trends show a resurgence (4- $6 \%$ of cancer in women) of disease in developed countries [106]. Since cervical cancer is mostly preceded by a long phase of precursor lesion, cellular atypia, various grades of CIN before progression to invasive cancer [107 - 112], prevention is the key. Developing countries including India are failing. Presently there are no available methods to differentiate CIN lesions that will progress to cancer from those that will not progress, though attempts are being made to identify factors which can help in prediction, as research continues. Based on the existing knowledge, UICC supported by multiple partners is spearheading the Cervical Cancer Initiative (CCI) to significantly reduce the incidence and mortality of women dying from the disease through targeted and resourced interventions [113].

\section{CONFLICT OF INTEREST}

The author confirms that this article content has no conflict of interest.

\section{ACKNOWLEDGEMENTS}

Declared none.

\section{REFERENCES}

[1] Sobti RC, Shekari M, Kordi Tamandani DM, Kaur P, Suri V, Huria A. Effect of NBS1 gene polymorphism on the risk of cervix carcinoma in a northern Indian population. Int J Biol Markers 2008; 23(3): 133-9. [PMID: 18949738]

[2] Shekari M, Sobti RC, Tamandani DM, Malekzadeh K, Kaur P, Suri V. Association of genetic polymorphism of the DNA base excision repair gene (APE-1 Asp/148 Glu) and HPV type (16/18) with the risk of cervix cancer in north Indian population. Cancer Biomark 2008; 4(2): 63-71.

[PMID: 18503157]

[3] Ferlay J, Shin H, Bray F, Forman D, Mathers C, Parkin D. GLOBOCAN 2008, cancer incidence and mortality worldwide: IARC CancerBase No 10. Lyon, France: International Agency for Research on Cancer 2010; p. 29. [http://dx.doi.org/10.1002/ijc.25516] [PMID: 21351269]

[4] Denny L, Quinn M, Sankaranarayanan R. Screening for cervical cancer in developing countries. Vaccine 2006; 24(S3): 71-7. [PMID: 16950020]

[5] Faggiano F, Partanen T, Kogevinas M, Boffetta P. Socioeconomic differences in cancer incidence and mortality. IARC Sci Publ 1997; (138): 65-176. [PMID: 9353664]

[6] Singh GK, Miller BA, Hankey BF, Edwards BK. Persistent area socioeconomic disparities in U.S. incidence of cervical cancer, mortality, stage, and survival, 1975-2000. Cancer 2004; 101(5): 1051-7. [http://dx.doi.org/10.1002/cncr.20467] [PMID: 15329915]

[7] Singh GK, Miller BA, Hankey BF, Edwards BK. Area socioeconomic variations in US cancer incidence, mortality, stage, treatment, and survival, 1975-1999. National Cancer Institute Bethesda (MD).: US Department of Health and Human Services, National Institutes of Health 2003.

[PMID: 15329915]

[8] Parikh S, Brennan P, Boffetta P. Meta-analysis of social inequality and the risk of cervical cancer. Int J Cancer 2003; 105(5): 687-91 [http://dx.doi.org/10.1002/ijc.11141] [PMID: 12740919]

[9] Singh GK, Williams SD, Siahpush M, Mulhollen A. Socioeconomic, rural-urban, and racial inequalities in US cancer mortality: Part I-All cancers and lung cancer and Part II-Colorectal, prostate, breast, and cervical cancers. J Cancer Epidemiol 2012; 2011 : 1-27. [http://dx.doi.org/10.1155/2011/107497] [PMID: 22496688]

[10] Singh GK. Rural-urban trends and patterns in cervical cancer mortality, incidence, stage, and survival in the United States, 1950-2008. J Commun Health 2012; 37(1): 217-23.

[http://dx.doi.org/10.1007/s10900-011-9439-6] [PMID: 21773819] 
[11] Cynthia H. Cervical cancer prevention and your diet by Madeline Vann, MPH 2009. Available from: http://www.everydayhealth.com/ cervical-cancer/prevention.aspx

[12] Arbyn M, Castellsagué X, de Sanjosé S, et al. Worldwide burden of cervical cancer in 2008. Ann Oncol 2011; 22(12): 2675-86. [http://dx.doi.org/10.1093/annonc/mdr015] [PMID: 21471563]

[13] Aswathy S, Quereshi MA, Kurian B, Leelamoni K. Cervical cancer screening: Current knowledge \& practice among women in a rural population of Kerala, India. Indian J Med Res 2012; 136(2): 205-10. [PMID: 22960886]

[14] Nanotechnology-based screening for HPV: Rethinking research priorities and outcomes; Gender innovations. Available from: http://gendered innovations.stanford.edu/case-studies/mubiop.html

[15] Desarrollo I. New nanoparticle that only attacks cervical cancer cells Investigación y Desarrollo 2014. Available from: http://www.sciencedaily.com/releases/2014/03/140314212122.htm

[16] Chhabra S, Barma S, Mahajan N. Compliance to therapy and recurrence in cervical cancer. Indian J Gynaecol Oncol 2011; 10(1): 39-42.

[17] Cervical Cancer. In-Depth Report. The New York Times. Available from: http://www.nytimes.com /health/guides/disease/ cervicalcancer/print.html

[18] Stockholm GR. Guidance report: Guidance for the introduction of HPV vaccines in EU countries 2008. Available at http://www.ecdc. europa.eu/en/Documents/4940_080_HPV_guidance. pdf

[19] Thompson D. Health Day Reporter HealthDay News Women's Health. Single Dose of HPV Vaccine May Be Enough to Guard Against Cervical Cancer. Available at http://www.medicalnewstoday.com /articles/268291.php

[20] McCoy K. Cervical Cancer Causes Beyond HPV 2009. Available at http://www.everydayhealth.com /cervical-cancer/other -causes.aspx

[21] Kleinberg MJ, Alvarez RW. Radical hysterectomy for carcinoma of the uterine cervix. Gynecology and Obstetrics Looseleaf 2004 ; p. 9.

[22] Mousavi A, Karimi Zarchi M, Gilani MM, et al. Radical hysterectomy in the elderly. World J Surg Oncol 2008; 6(1): 38. [http://dx.doi.org/10.1186/1477-7819-6-38] [PMID: 18394193]

[23] Frederick P, Whitworth J, Alvarez R. Radical hysterectomy for carcinoma of the uterine cervix. Glob Libr Women's Med (ISSN: 1756-2228) 2011. Available at: http://www.glowm.com/section_view/item/232 [http://dx.doi.org/10.3843/GLOWM.10232]

[24] Wright TC Jr, Gagnon S, Richart RM, Ferenczy A. Treatment of cervical intraepithelial neoplasia using the loop electrosurgical excision procedure. Obstet Gynecol 1992; 79(2): 173-8. [PMID: 1731281]

[25] Naumann RW, Bell MC, Alvarez RD, et al. LLETZ is an acceptable alternative to diagnostic cold-knife conization. Gynecol Oncol 1994; 55(2): 224-8.

[http://dx.doi.org/10.1006/gyno.1994.1281] [PMID: 7959288]

[26] Girardi F, Heydarfadai M, Koroschetz F, Pickel H, Winter R. Cold-knife conization versus loop excision: histopathologic and clinical results of a randomized trial. Gynecol Oncol 1994; 55(3 Pt 1): 368-70. [http://dx.doi.org/10.1006/gyno.1994.1308] [PMID: 7835776]

[27] Widrich T, Kennedy AW, Myers TM, Hart WR, Wirth S. Adenocarcinoma in situ of the uterine cervix: management and outcome. Gynecol Oncol 1996; 61(3): 304-8. [http://dx.doi.org/10.1006/gyno.1996.0147] [PMID: 8641606]

[28] Shumsky AG, Stuart GC, Nation J. Carcinoma of the cervix following conservative management of cervical intraepithelial neoplasia. Gynecol Oncol 1994; 53(1): 50-4.

[http://dx.doi.org/10.1006/gyno.1994.1086] [PMID: 8175022]

[29] Creasman WT, Zaino RJ, Major FJ, et al. Early invasive carcinoma of the cervix (3 to $5 \mathrm{~mm}$ invasion): Risk factors and prognosis: A Gynecologic Oncology Group. Am J Obstet Gynecol 1998; 178: 62-5.

[30] Sevin BU, Nadji M, Averette HE, Hilsenbeck S, Smith D, Lampe B. Microinvasive carcinoma of the cervix. Cancer 1992; 70(8): 2121-8. [http://dx.doi.org/10.1002/1097-0142 (19921015)70:8<2121: :AID-CNCR2820700819 >3.0.CO;2-S] [PMID: 1394041]

[31] Jones WB, Mercer GO, Lewis JL Jr, Rubin SC, Hoskins WJ. Early invasive carcinoma of the cervix. Gynecol Oncol 1993; 51(1): 26-32. [http://dx.doi.org/10.1006/gyno.1993.1241] [PMID: 8244170]

[32] Magrina JF, Goodrich MA, Lidner TK, Weaver AL, Cornella JL, Podratz KC. Modified radical hysterectomy in the treatment of early squamous cervical cancer. Gynecol Oncol 1999; 72(2): 183-6. [http://dx.doi.org/10.1006/gyno.1998.5245] [PMID: 10021298]

[33] SIGN. Scottish Intercollegiate Guidelines Network, Management of cervical cancer, A national clinical guideline 2008. Available at: http://www.sign.ac.uk/pdf/sign99.pdf

[34] Rotman M, Sedlis A, Piedmonte MR, et al. A phase III randomized trial of postoperative pelvic irradiation in Stage IB cervical carcinoma with poor prognostic features: Follow-up of a gynecologic oncology group study. Int J Radiat Oncol, Biol, Phys 2006; 65(1): 169-76.

[35] Landoni F, Maneo A, Colombo A, et al. Randomised study of radical surgery versusradiotherapy for stage Ib-IIa cervical cancer. Lancet 1997; 350(9077): 535-40. 
[http://dx.doi.org/10.1016/S0140 -6736(97)02250 -2] [PMID: 9284774]

[36] Maas CP, ter Kuile MM, Laan E, et al. Objective assessment of sexual arousal in women with a history of hysterectomy. BJOG 2004; 111(5): $456-62$.

[http://dx.doi.org/10.1111/j.1471-0528.2004.00104.x] [PMID: 15104610]

[37] Yabuki Y, Asamoto A, Hoshiba T, Nishimoto H, Satou N. A new proposal for radical hysterectomy. Gynecol Oncol 1996; 62(3): 370-8. [http://dx.doi.org/10.1006/gyno.1996.0251] [PMID: 8812535]

[38] Höckel M, Konerding MA, Heussel CP. Liposuction-assisted nerve-sparing extended radical hysterectomy: oncologic rationale, surgical anatomy, and feasibility study. Am J Obstet Gynecol 1998; 178(5): 971-6.

[http://dx.doi.org/10.1016/S0002 -9378(98)70533 -2] [PMID: 9609569]

[39] Forney JP. The effect of radical hysterectomy on bladder physiology. Am J Obstet Gynecol 1980; 138(4): 374-82. [http://dx.doi.org/10.1016/0002 -9378(80)90132 -5] [PMID: 7191638]

[40] Ralph G, Winter R, Michelitsch L, Tamussino K. Radicality of parametrial resection and dysfunction of the lower urinary tract after radical hysterectomy. Eur J Gynaecol Oncol 1991; 12(1): 27-30. [PMID: 2050156]

[41] Ercoli A, Delmas V, Gadonneix P, et al. Classical and nerve-sparing radical hysterectomy: an evaluation of the risk of injury to the autonomous pelvic nerves. Surg Radiol Anat 2003; 25(3-4): 200-6. [http://dx.doi.org/10.1007/s00276-003-0137-7] [PMID: 12910382]

[42] Anwar H, El Shazly SE, El Zoheiry M, Metwally ME, Mohsen MA. Nerve sparing radical hysterectomy: Feasibility and effect on bladder function. J Egypt Natl Canc Inst 2003; 15(1): 11-5.

[43] Trimbos JB, Franchi M, Zanaboni F, Velden JV, Vergote I. 'State of the art' of radical hysterectomy; current practice in European oncology centres. Eur J Cancer 2004; 40(3): 375-8.

[http://dx.doi.org/10.1016/j.ejca.2003.09.017] [PMID: 14746855]

[44] Cunningham MJ, Dunton CJ, Corn B, et al. Extended-field radiation therapy in early-stage cervical carcinoma: survival and complications. Gynecol Oncol 1991; 43(1): 51-4.

[http://dx.doi.org/10.1016/0090-8258 (91)90008-S] [PMID: 1959788]

[45] Vigliotti AP, Wen B, Hussey DH, et al. Extended field irradiation for carcinoma of the uterine cervix with positive periaortic nodes Int J Radiat Oncol Biol Phys 1992; 23(3): 501-09. [http://dx.doi.org/10.1016/0360 -3016(92) 90004-2]

[46] HKJGOM. Bladder function following nerve-sparing radical hysterectomy: A retrospective cohort study in Hong Kong 2012; $12(1)$ : 43-9.

[47] Hertel H, Köhler C, Michels W, Possover M, Tozzi R, Schneider A. Laparoscopic-assisted radical vaginal hysterectomy (LARVH): prospective evaluation of 200 patients with cervical cancer. Gynecol Oncol 2003; 90(3): 505-11. [http://dx.doi.org/10.1016/S0090 -8258(03)00378 -0] [PMID: 13678717]

[48] Naik R, Jackson KS, Lopes A, Cross P, Henry JA. Laparoscopic assisted radical vaginal hysterectomy versusradical abdominal hysterectomy-a randomised phase II trial: perioperative outcomes and surgicopathological measurements. BJOG 2010; 117(6): 746-51. [http://dx.doi.org/10.1111/j.1471-0528. 2010.02479.x] [PMID: 20236108]

[49] Ramirez PT, Schmeler KM, Wolf JK, Brown J, Soliman PT. Robotic radical parametrectomy and pelvic lymphadenectomy in patients with invasive cervical cancer. Gynecol Oncol 2008; 111(1): 18-21.

[http://dx.doi.org/10.1016/ j.ygyno.2008 .06.011] [PMID: 18639329]

[50] Shepherd JH, Mould T, Oram DH. Radical trachelectomy in early stage carcinoma of the cervix: outcome as judged by recurrence and fertility rates. BJOG 2001; 108(8): 882-5.

[http://dx.doi.org/10.1111/ j.1471-0528.2001 .00212.x] [PMID: 11510717]

[51] Speiser D, Köhler C, Schneider A, Mangler M. Radical vaginal trachelectomy: a fertility-preserving procedure in early cervical cancer in young women. Dtsch Arztebl Int 2013; 110(17): 289-95. [PMID: 23671476]

[52] Sedlis A, Bundy BN, Rotman MZ, Lentz SS, Muderspach LI, Zaino RJ. A randomized trial of pelvic radiation therapy versusno further therapy in selected patients with stage IB carcinoma of the cervix after radical hysterectomy and pelvic lymphadenectomy: A Gynecologic Oncology Group Study. Gynecol Oncol 1999; 73(2): 177-83. [http://dx.doi.org/10.1006/gyno.1999.5387] [PMID: 10329031]

[53] Geisler JP, Orr CJ, Khurshid N, Phibbs G, Manahan KJ. Robotically assisted laparoscopic radical hysterectomy compared with open radical hysterectomy. Int J Gynecol Cancer 2010; 20(3): 438-42. [http://dx.doi.org/10.1111/IGC.0b013e3181cf5c2c] [PMID: 20375811]

[54] Boggess JF, Gehrig PA, Cantrell L, et al. A case-control study of robot-assisted type III radical hysterectomy with pelvic lymph node dissection compared with open radical hysterectomy. Am J Obstet Gynecol 2008; 199(4): 357.e1-7. [http://dx.doi.org/10.1016/j.ajog.2008.06.058]

[55] Fanning J, Fenton B, Purohit M. Robotic radical hysterectomy. Am J Obstet Gynecol 2008; 198(6): 649.e1-4. [http://dx.doi.org/10.1016/j.ajog.2007.11.002] 
[56] Ko EM, Muto MG, Berkowitz RS, Feltmate CM. Robotic versusopen radical hysterectomy: a comparative study at a single institution. Gynecol Oncol 2008; 111(3): 425-30. [http://dx.doi.org/10.1016/j.ygyno.2008.08.016] [PMID: 18929400]

[57] Magrina JF, Kho RM, Weaver AL, Montero RP, Magtibay PM. Robotic radical hysterectomy: comparison with laparoscopy and laparotomy. Gynecol Oncol 2008; 109(1): 86-91. [http://dx.doi.org/10.1016/j.ygyno.2008.01.011] [PMID: 18279944]

[58] Sert B, Abeler V. Robotic radical hysterectomy in early-stage cervical carcinoma patients, comparing results with total laparoscopic radical hysterectomy cases. The future is now? Int J Med Robot 2007; 3(3): 224-8. [http://dx.doi.org/10.1002/rcs.152] [PMID: 17924449]

[59] Kruijdenberg CB, van den Einden LC, Hendriks JC, Zusterzeel PL, Bekkers RL. Robot-assisted versus total laparoscopic radical hysterectomy in early cervical cancer, a review. Gynecol Oncol 2011; 120(3): 334-9. [http://dx.doi.org/10.1016/j.ygyno.2010.12.342] [PMID: 21236473]

[60] Side effects of radiotherapy/brachytherapy. Available from: http://www.jostrust.org.uk/about-cervical-cancer/cervical-cancer/ treatments/radiotherapy/side-effects-of-radiotherapy-brachytherapy

[61] Eldridge L. Lung Cancer Expert, Side Effects of Radiation Therapy for Lung Cancer. Available from: http://lungcancer.about.com/od/ treatmentoflungcancer/a/radsideeffects.htm

[62] Wong C. Natural Remedies for Radiation Side Effects. Available from: http://altmedicine.about.com/od/cance1/a/radiation_side_effects. $\mathrm{htm}$ ?utm_term =after effects of radio therapy \&utm_content=p1-main-4-

[63] Radiation therapy for cervical cancer increases risk for colorectal cancer, University of Texas Medical Branch at Galveston 2014. Available from: http://www.sciencedaily.com/releases /2014/04/140417101454.htm

[64] Nag S, Erickson B, Thomadsen B, Orton C, Demanes J D, Petereit D. The American Brachytherapy Society recommendations for high-doserate brachytherapy for carcinoma of the cervix. Int J Radiat Oncol, Biol, Phys 2000; 48(1): 201-11.

[http://dx.doi.org/10.1016/S0360-3016(00)00497-1]

[65] Jabir NR, Tabrez S, Ashraf GM, Shakil S, Damanhouri GA, Kamal MA. Nanotechnology-based approaches in anticancer research. Int J Nanomedicine 2012; 7: 4391-408. [PMID: 22927757]

[66] Rotman M, Pajak TF, Choi K, et al. Prophylactic extended-field irradiation of para-aortic lymph nodes in stages IIB and bulky IB and IIA cervical carcinomas. Ten-year treatment results of RTOG 79-20. JAMA 1995; 274(5): 387-93. [http://dx.doi.org/10.1001/jama.1995.03530050035029] [PMID: 7616634]

[67] Whitney CW, Sause W, Bundy BN, et al. Randomized comparison of fluorouracil plus cisplatin versus hydroxyurea as an adjunct to radiation therapy in stage IIB-IVA carcinoma of the cervix with negative para-aortic lymph nodes: A Gynecologic Oncology Group and Southwest Oncology Group study. J Clin Oncol 1999; 17(5): 1339-48. [PMID: 10334517]

[68] Fanning J, Andrews S. Early postoperative feeding after major gynecologic surgery: evidence-based scientific medicine. Am J Obstet Gynecol $2001 ; 185(1): 1-4$

[http://dx.doi.org/10.1067/mob.2001.113911] [PMID: 11483895]

[69] Weiser E B, Bundy B N, Hoskins W J, et al. Extraperitoneal versustransperitoneal selective paraaortic lymphadenectomy in the pretreatment surgical staging of advanced cervical carcinoma (a Gynecologic Oncology Group study). Gyneco Oncol 1989; 33(3): 283-89.

[70] Fine B A, Hempling R E, Piver M S, Baker T R, McAuley M, Driscoll D. Severe radiation morbidity in carcinoma of the cervix: impact of pretherapy surgical staging and previous surgery. Int J Radiat Oncol Biol Phys 1995; 31(4): 717-23. [http://dx.doi.org/10.1016/0360-3016(94)00458-7]

[71] Estape RE, Angioli R, Madrigal M, et al. Close vaginal margins as a prognostic factor after radical hysterectomy. Gynecol Oncol 1998; 68(3): $229-32$. [http://dx.doi.org/10.1006/gyno.1998.4960] [PMID: 9570971]

[72] Morris M, Eifel PJ, Lu J, et al. Pelvic radiation with concurrent chemotherapy compared with pelvic and para-aortic radiation for high-risk cervical cancer. N Engl J Med 1999; 340(15): 1137-43 [http://dx.doi.org/10.1056/NEJM199904153401501] [PMID: 10202164]

[73] Rose PG, Bundy BN, Watkins EB, et al. Concurrent cisplatin-based radiotherapy and chemotherapy for locally advanced cervical cancer. $\mathrm{N}$ Engl J Med 1999; 340(15): 1144-53. [http://dx.doi.org/10.1056/NEJM199904153401502] [PMID: 10202165]

[74] Tillmanns TD, Kamelle SA, Abudayyeh I, et al. Panniculectomy with simultaneous gynecologic oncology surgery. Gynecol Oncol 2001; 83(3): 518-22. [http://dx.doi.org/10.1006/gyno.2001.6414] [PMID: 11733965]

[75] Jensen PT, Groenvold M, Klee MC, Thranov I, Petersen MA, Machin D. Early-stage cervical carcinoma, radical hysterectomy, and sexual function. A longitudinal study. Cancer 2004; 100(1): 97-106. [http://dx.doi.org/10.1002/cncr.11877] [PMID: 14692029] 
[76] Rees PM, Fowler CJ, Maas CP. Sexual function in men and women with neurological disorders. Lancet 2007; 369(9560): $512-25$. [http://dx.doi.org/10.1016/S0140-6736(07)60238-4] [PMID: 17292771]

[77] Low JA, Mauger GM, Carmichael JA. The effect of Wertheim hysterectomy upon bladder and urethral function. Am J Obstet Gynecol 1981; 139(7): 826-34. [http://dx.doi.org/10.1016/0002-9378(81)90551-2] [PMID: 7193976]

[78] Scotti RJ, Bergman A, Bhatia N N, Ostergard DR. Urodynamic changes in urethrovesical function after radical hysterectomy. Obstet Gynecol 1986; 68(1): 111-20.

[79] Ditto A, Martinelli F, Borreani C, et al. Quality of life and sexual, bladder, and intestinal dysfunctions after class III nerve-sparing and class II radical hysterectomies: a questionnaire-based study. Int J Gynecol Cancer 2009; 19(5): 953-7. [http://dx.doi.org/10.1111/IGC.0b013e3181a2d171] [PMID: 19574791]

[80] Wu J, Liu X, Hua K, Hu C, Chen X, Lu X. Effect of nerve-sparing radical hysterectomy on bladder function recovery and quality of life in patients with cervical carcinoma. Int J Gynecol Cancer 2010; 20(5): 905-9. [http://dx.doi.org/10.1111/IGC.0b013e3181df99c0] [PMID: 20606542]

[81] Zullo MA, Manci N, Angioli R, Muzii L, Panici PB. Vesical dysfunctions after radical hysterectomy for cervical cancer: a critical review. Crit Rev Oncol Hematol 2003; 48(3): 287-93. [http://dx.doi.org/10.1016/S1040-8428(03)00125-2] [PMID: 14693341]

[82] Rana J, Rong SH, Mehata S. Retention of urine after radical hysterectomy for cervical cancer. Health Perspect 2012; 10: 1-4.

[83] Brooks RA, Wright JD, Powell MA, et al. Long-term assessment of bladder and bowel dysfunction after radical hysterectomy. Gynecol Oncol 2009; 114(1): 75-9. [http://dx.doi.org/10.1016/j.ygyno.2009.03.036] [PMID: 19410279]

[84] Lim KC, Howells RE, Evans AS. The role of clinical follow up in early stage cervical cancer in South Wales. BJOG 2004; $111(12)$ : 1444-8. [http://dx.doi.org/10.1111/j.1471-0528.2004.00280.x] [PMID: 15663133]

[85] Delgado G, Bundy B, Zaino R, Sevin B-U, Creasman WT, Major F. Prospective surgical-pathological study of disease-free interval in patients with stage IB squamous cell carcinoma of the cervix: a Gynecologic Oncology Group study. Gynecol Oncol 1990; $38(3)$ : 352-7. [http://dx.doi.org/10.1016/0090-8258(90)90072-S] [PMID: 2227547]

[86] Alvarez RD, Potter ME, Soong S-J, et al. Rationale for using pathologic tumor dimensions and nodal status to subclassify surgically treated stage IB cervical cancer patients. Gynecol Oncol 1991; 43(2): 108-12. [http://dx.doi.org/10.1016/0090-8258(91)90054-9] [PMID: 1743550]

[87] Lukaszuk K, Liss J, Wozniak I, Sliwinski W, Emerich J, Wojcikowski C. HPV and histological status of pelvic lymph node metastases in cervical cancer: a prospective study. J Clin Pathol 2004; 57(5): 472-6. [http://dx.doi.org/10.1136/jcp.2003.009852] [PMID: 15113853]

[88] Denschlag D, Gabriel B, Mueller-Lantzsch C, et al. Evaluation of patients after extraperitoneal lymph node dissection for cervical cancer. Gynecol Oncol 2005; 96(3): 658-64.

[http://dx.doi.org/10.1016/j.ygyno.2004.08.053] [PMID: 15721408]

[89] Ferrandina G, Distefano M, Ludovisi M, et al. Lymph node involvement in locally advanced cervical cancer patients administered preoperative chemoradiation versuschemotherapy. Ann Surg Oncol 2007; 14(3): 1129-35. [http://dx.doi.org/10.1245/s10434-006-9252-0] [PMID: 17206484]

[90] Delaloye JF, Coucke PA, Pampallona S, De Grandi P. Effect of total treatment of time on event-free survival in carcinoma of the cervix. Gynecol Oncol 1996; 60(1): 42-8. [http://dx.doi.org/10.1006/gyno.1996.0009] [PMID: 8557226]

[91] Fyles A, Keane TJ, Barton M, Simm J. The effect of treatment duration in the local control of cervix cancer. Radiother Oncol 1992; 25(4): 273-9. [http://dx.doi.org/10.1016/0167-8140(92)90247-R] [PMID: 1480773]

[92] Ohara K, Sugahara S, Kagei K, et al. Retrospective comparison of clinical outcome between radiotherapy alone and surgery plus postoperative radiotherapy in the treatment of stages IB-IIB cervical squamous cell carcinoma. Radiat Med 2004; $22(1)$ : $42-8$. [PMID: 15053175]

[93] Ghaemmaghami F, Saleh-Gargari S, Sahebdel B, Behtash N, Samiei F. Risk factors and clinical aspects of recurrent invasive cervical carcinoma. J Obstet Gynaecol India 2012; 62(6): 674-8. [http://dx.doi.org/10.1007/s13224-012-0227-8] [PMID: 24293846]

[94] Comerci G, Bolger BS, Flannelly G, Maini M, de Barros Lopes A, Monaghan JM. Prognostic factors in surgically treated stage IB-IIB carcinoma of the cervix with negative lymph nodes. Int J Gynecol Cancer 1998; 8(1): 23-6. [http://dx.doi.org/10.1046/j.1525-1438.1998.09754.x] [PMID: 11576283]

[95] Yamazawa K, Matsui H, Ishikura H, Seki K, Mitsuhashi A, Sekiya S. Significance of perivascular lymphocytic infiltrates on survival of patients with invasive cervical cancer. J Immunother 2003; 26(2): 149-55. [http://dx.doi.org/10.1097/00002371-200303000-00007] [PMID: 12616106]

[96] Delgado; Radiation Oncology/Cervix/Early Stage Nonbulky 2013. Available from: http://en.wikibooks.org/wiki/Radiation _Oncology/Cervix/Early_Stage_Nonbulky 
[97] Duyn A, Van Eijkeren M, Kenter G, Zwinderman K, Ansink A. Recurrent cervical cancer: detection and prognosis. Acta Obstet Gynecol Scand 2002; 81(8): 759-63. [http://dx.doi.org/10.1034/j.1600-0412.2002.810414.x] [PMID: 12174162]

[98] Mahé M-A, Gérard J-P, Dubois J-B, et al. Intraoperative radiation therapy in recurrent carcinoma of the uterine cervix: report of the French intraoperative group on 70 patients. Int J Radiat Oncol Biol Phys 1996; 34(1): 21-6. [http://dx.doi.org/10.1016/0360-3016(95)02089-6]

[99] Delgado G, Bundy B, Zaino R, et al. Prospective surgical-pathological study of disease-free interval in patients with stage IB squamous cell carcinoma of the cervix: A gynaecologic oncology group study. Gynecol Oncol 1990; 38(3): 352-57.

[100] Obermair A, Gebski V, Frumovitz M, et al. A phase III randomized clinical trial comparing laparoscopic or robotic radical hysterectomy with abdominal radical hysterectomy in patients with early stage cervical cancer. J Minim Invasive Gynecol 2008; 15(5): 584-8. [http://dx.doi.org/10.1016/j.jmig.2008.06.013] [PMID: 18722970]

[101] Morgan DJ, Hunter DC, McCracken G, McClelland HR, Price JH, Dobbs SP. Is laparoscopically assisted radical vaginal hysterectomy for cervical carcinoma safe? A case control study with follow up. BJOG 2007; 114(5): 537-42. [http://dx.doi.org/10.1111/j.1471-0528.2007.01291.x] [PMID: 17355358]

[102] Chirenje ZM, Rusakaniko S, Kirumbi L, et al. Situation analysis for cervical cancer diagnosis and treatment in east, central and southern African countries. Bull World Health Organ 2001; 79(2): 127-32. [PMID: 11242819]

[103] Anorlu RI. Cervical cancer: The sub-Saharan African perspective. Reprod Health Matt 2008; 16(32): 41-9. [http://dx.doi.org/10.1016/S0968-8080(08)32415-X] [PMID: 19027621]

[104] Help Age International. State of the world's older people 2002 London: Help Age International 2002. Available from: http://www.helpage.org/images/pdfs/SOTWOPeng.pdf

[105] Sherris J, Castro W, Levin C, Dzuba I, Arrossi S. Alliance for Cervical Cancer Prevention (ACCP). The case for investing in cervical cancer prevention. Cervical Cancer Prev Issues Depth 2004; (3): 1. Available from: http://screening.iarc.fr/doc/RH_accp_case.pdf

[106] Swan J, Breen N, Coates RJ, Rimer BK, Lee NC. Progress in cancer screening practices in the United States: results from the 2000 National Health Interview Survey. Cancer 2003; 97(6): 1528-40. [http://dx.doi.org/10.1002/cncr.11208] [PMID: 12627518]

[107] Crum CP, McLachlin CM. Cervical intraepithelial neoplasia. J Cell Biochem Suppl 1995; 23(S23): 71-9. [http://dx.doi.org/10.1002/jcb.240590910] [PMID: 8747380]

[108] Rapp L, Chen JJ. The papillomavirus E6 proteins. Biochimica et Biophysica Acta (BBA). Rev Can 1998; $1378(1)$ : F1-F19.

[109] Schiffman M, Kjaer SK. Natural history of anogenital human papillomavirus infection and neoplasia. JNCi Monographs 2003; (31): 14-9. [http://dx.doi.org/10.1093/oxfordjournals.jncimonographs.a003476]

[110] Agorastos T, Miliaras D, Lambropoulos AF, et al. Detection and typing of human papillomavirus DNA in uterine cervices with coexistent grade I and grade III intraepithelial neoplasia: biologic progression or independent lesions? Eur J Obstet Gynecol Reprod Biol 2005; 121(1): 99-103.

[http://dx.doi.org/10.1016/j.ejogrb.2004.11.024] [PMID: 15949888]

[111] Hillemanns P, Wang X, Staehle S, Michels W, Dannecker C. Evaluation of different treatment modalities for vulvar intraepithelial neoplasia (VIN): $\mathrm{CO}(2)$ laser vaporization, photodynamic therapy, excision and vulvectomy. Gynecol Oncol 2006; 100(2): 271-5. [http://dx.doi.org/10.1016/j.ygyno.2005.08.012] [PMID: 16169064]

[112] IARC. A Practical Manual On Visual Screening For Cervical Neoplasia. Available from: http://screening.iarc.fr/viavili.php

[113] A Membership Organization Fighting Cancer Together; Cervical Cancer Initiative (CCI) 2014. Available from http://www.uicc.org/ programmes/cci

Received: January 7, 2015

Revised: September 1, 2015

Accepted: September 15, 2015

(C) S. Chhabra; Licensee Bentham Open.

This is an open access article licensed under the terms of the Creative Commons Attribution-Non-Commercial 4.0 International Public License (CC BY-NC 4.0) (https://creativecommons.org/licenses/by-nc/4.0/legalcode), which permits unrestricted, non-commercial use, distribution and reproduction in any medium, provided the work is properly cited. 